\title{
Procedural Signaling, Party Loyalty, and Traceability in the U.S. House of Representatives
}

Political Research Quarterly

2014, Vol. 67(4) 729-742

(C) 2014 University of Utah

Reprints and permissions:

sagepub.com/journalsPermissions.nav DOI: $10.1177 / 1065912914536469$

prq.sagepub.com

(S)AGE

\author{
Jamie L. Carson', Michael H. Crespin ${ }^{2}$, and Anthony J. Madonna'
}

\begin{abstract}
In this article, we take advantage of a new source of data providing updates from the Majority Leader's Office that signal the leadership's positions on floor votes. We offer a more nuanced explanation of voting in the U.S. House as our findings suggest that not all procedural votes are created equal. While the most liberal members of the party vote with the leadership on procedural votes at high rates and nearly 100 percent of the time when signaled by the majority leader, moderate members are significantly less likely to support the party and are not responsive to these signals.
\end{abstract}

\section{Keywords}

legislative process, party loyalty, signaling, traceability

Proponents of partisan influence in Congress (e.g., Aldrich and Rohde 2000; Cox and McCubbins 2005, 2007; Rohde 1991) believe that legislative outcomes can be manipulated for both electoral and policy benefits. Generally, these scholars argue that party organizations have two ways of manipulating these outcomes-negative and positive agenda control. The former often entails keeping divisive legislative proposals off the agenda, especially if party leaders suspect that they will lose (Cox and McCubbins 2005; Gailmard and Jenkins 2007; Jenkins and Monroe 2012a). Positive agenda control, on the other hand, typically entails arm-twisting, vote buying, or other aggressive tactics associated with whipping individual legislators (Finocchiaro and Rohde 2008; Rohde 1991). These strategies help to ensure that the majority party is disproportionally successful in obtaining their desired policy outcomes.

Underlying these theories is the assumption that the rank-and-file will vote with the party leadership on important agenda-setting votes to promote the desired outcome. More specifically, cartel theory states, “. . . cartel members expect rank-and-file members to support the agenda-setting decisions ..." and ". . . the cartel's leadership takes action to maintain cooperation and coordination within the cartel" (Cox and McCubbins 2005, 24). To date, party theorists have done an excellent job describing the macro-level concepts and rationale behind why parties seek to influence procedural votes in Congress. However, there has been less research on how the leadership goes about the day-to-day task of coordinating with the rank-and-file to assure the desired outcomes on agenda-setting procedural votes.
In this article, we introduce an original dataset of emails sent from the Democratic Majority Leader's office that signal the leadership's positions on upcoming legislation and floor votes during the 110th and 111th Congresses. These emails provide direct evidence of how the party tries to maintain coordination among the rankand-file and, more importantly, which votes the leadership views as important for setting the procedural table. We can then test hypotheses related to which members of the rank-and-file will support the leadership when asked to do so. Our results indicate that responsiveness to party signals is not uniformly concentrated among majority party members; rather, it varies across the ideological spectrum of the majority caucus.

The organization of the article is as follows. In the next section, we review the literature on agenda control and party influence in Congress. We then place what we call "signaling" in the broader institutional and procedural context and discuss how it can facilitate party leaders' goals. We next introduce the data used in our analysis, particularly as it pertains to how the party leadership sets the agenda on procedural matters. We present descriptive evidence before turning to more systematic analysis of

\footnotetext{
'The University of Georgia, Athens, USA

${ }^{2}$ University of Oklahoma, Norman, USA

Corresponding Author:

Michael H. Crespin, Carl Albert Center, Department of Political

Science, University of Oklahoma, 630 Parrington Oval, Room I0I,

Norman, OK 73019-403I, USA.

Email:michael.crespin@gmail.com
} 
how often legislators vote with the leadership on signaled votes. The final section concludes and discusses the implications of our findings.

\section{Theories of Partisan Influence in Congress}

The past two decades has witnessed an explosion in the growth of scholarship detailing the influence of political parties in Congress. Initially, students of congressional politics set out to address the resurgence in parties after a substantial decline in the preceding decades (see, for example, Rohde 1991). Soon thereafter, Krehbiel (1993) challenged this view of parties by arguing that for party influence to be significant, it must be documented independently of legislators' own personal preferences. In response to this challenge issued by Krehbiel, numerous attempts were made in the ensuing years to demonstrate that parties do independently influence legislative outcomes in Congress (see, for example, Aldrich and Rohde 2000; Binder, Lawrence, and Maltzman 1999; Evans and Grandy 2009).

During the last decade, emphasis has gradually shifted away from the question of whether parties matter in Congress to a broader, theoretical examination of how parties influence policy outcomes. Cox and McCubbins (2005) argue the majority party's primary source of influence is through negative agenda control. Specifically, the majority party will block "bad" legislation, or amendments, from coming to the floor if such legislation is likely to split or highlight divisions within the party. This is often accomplished through the practice of using restrictive rules issued by the Rules Committee (Marshall 2005; Monroe and Robinson 2008).

Nevertheless, the very nature of the legislative process dictates that controversial policies must be voted on in Congress from time to time to bolster the party's record of accomplishments. To ensure success on divisive issues, party leaders seek near unanimous support on procedural matters that dictate the manner in which controversial bills are debated and considered on the floor. These procedural factors are less visible to constituents for the purposes of reelection (Arnold 1990) but are essential to the party for ensuring legislative passage (Cox and Poole 2002; Finocchiaro and Rohde 2008).

Recent work has confirmed the theoretical intuition that these procedural votes are of the highest priority to party organizations. Snyder and Groseclose (2000), for example, find that party pressure is elevated on procedural and platform-type votes. ${ }^{1}$ Cox and Poole (2002) also find increased party effects on procedural votessuch as votes on special rules or chamber organization. Crespin (2010) and Jenkins, Crespin, and Carson (2005) show that members are responsive to party pressure on procedural votes under varying circumstances. In addition, Roberts (2005) finds elevated party pressure on another procedural tool, the motion to recommit.

The theory underlying increased party pressure on procedural votes is twofold. First, as discussed above, these votes are extremely important to the party. They allow the majority to bring certain issues to the floor, regulate the scope of the substance under consideration, and control the length and nature of the debate. This has important implications for both policy output and electioneering. Second, scholars note that procedural votes lack the "traceability" of amendment or final passage votes (Arnold 1990). Thus, constituents are less likely to punish members for supporting the party's position on a procedural matter (Arnold 1990; Cox and McCubbins 2005, 2007; Jenkins and Monroe 2012a, 2012b; Monroe and Robinson 2008).

Despite this apparent lack of traceability, recent work has demonstrated that party unity on procedural votes is by no means guaranteed and support by all rank-and-file members is not unconditional. Finocchiaro and Rohde (2008) report that the majority party was occasionally "rolled" on votes to adopt special rules (on this point, see also Carson, Monroe, and Robinson 2011), concluding that the majority must use some positive agenda control techniques on these procedural votes. ${ }^{2}$ While constituents may not be able to trace voting on procedure with policy outcomes, Smith, Ostrander, and Pope (2013) find that opponents are just as likely to exploit a senators' vote on a procedural matter as they are a substantive vote. There is anecdotal evidence that House candidates will run ads attacking incumbents for voting with the leadership at high rates even if many of those votes are procedural in nature. ${ }^{3}$ In sum, while the evidence suggests greater party influence on procedural matters, little systematic research examines the micro-level factors associated with how party leaders seek to specifically manipulate procedural outcomes or which types of procedural votes the party will seek to influence. Finally, while the literature shows the majority rarely loses on procedural votes, support is not unconditional, and it does not delve into detail on which members are most likely to support the party when asked.

\section{Partisan Influence and Procedural Signaling}

In the following section, we develop expectations about when the majority party will ask for support on agendasetting votes and then who we think is likely to respond. We call this ask a "signal" to differentiate from whipping because, to us, the processes are distinct from one another. As Evans and Grandy (2009) assert, the whip system in Congress is used largely to facilitate the 
passage of legislation, especially when legislators are wavering in their support of key tenants of the majority's agenda. Legislators within this system convey information to leaders and try to build consensus to ensure that rank-and-file members fall in line on tough votes. However, the whip system is not the only organization that sends voting preferences to the rank-and-file. The Majority Leader's office, which is concerned with scheduling votes (Oleszek 2013), is also an important player in the legislative process. This procedure is somewhat different though because the Leader's office does not appear to collect vote preferences the way the whip does, and the process does not allow for time to build consensus. We will discuss the specific mechanism by which the leadership signals the rank-and-file when we introduce our data.

\section{When to Signal}

Building off of the preceding discussion, we believe the party is more likely to signal its position on certain types of procedural votes for several reasons. First, procedural votes can be confusing to some legislators. Many rules are technical in nature and the party will often provide as much guidance as possible to alleviate problems associated with information asymmetry when it comes to voting on them. Second, procedural matters govern the manner in which a bill is debated, amended, and considered on the floor. By dictating the amendment process, rules have the ability to centralize proposal power under the majority party leadership. In other words, they allow the leadership to determine what gets voted upon on the floor and what does not (Cox 2000; Cox and McCubbins 2005; Rohde 1991; Smith 1989). As a result, this can be controversial for majority party members across the ideological spectrum.

Votes on procedure are occasionally more controversial than votes on substance. During consideration of H.R. 4853, the Tax Relief, Unemployment Insurance Reauthorization and Job Creation Act of 2010, for instance, the Rules Committee produced a closed rule $(\mathrm{H}$. Res. 1745) that barred all amendments. ${ }^{4}$ Predictably, minority party Republicans were united in their opposition to the rule, and Minority Leader John Boehner (R-OH) went so far as to deem it "chicken crap" (Sloan 2010). However, the rule also sparked dissension from majority party moderates who sought to offer amendments cutting taxes. Ultimately, H. Res. 1745 passed 213203 , with thirty majority party Democrats voting against it. The bill itself was actually adopted by a more comfortable margin, passing 234-188.

As H. Res. 1745 suggests, not all procedural votes are created equal. We anticipate the majority party would be more likely to call for support on special rule votes and motions to order the previous question on special rules than other types of procedural motions. This, we believe, is a result of a combination of importance and timing. Because the majority party controls the Rules Committee, leaders are aware of the content of the rule reported by the committee. In addition, special rules are written relatively quickly prior to floor consideration so the rankand-file may not have time to study them before they come to a vote. Failure to adopt the rule can result in the defeat of the underlying bill or substantial policy concessions. In addition, while the House often orders the previous question on the rule (cutting off debate to vote on the motion) without objection, there will occasionally be a roll-call vote taken on it. Defeating the previous question motion allows the minority to amend a rule, and a defeat is devastating to majority party agenda control. Once the previous question motion is ordered, a vote is taken on the rule itself. Given the important consequences that the failure of these motions could have-coupled with the fact that the majority leadership is aware of their content and timing ahead of time - we anticipate the party is likely to signal its position on these matters. ${ }^{5}$

The importance of timing and content is made even clearer when one considers another key type of procedural vote: the motion to recommit. While scholars have confirmed the important role the motion to recommit can play (Krehbiel and Meirowitz 2002; Roberts 2005), its quick introduction should limit the majority party's ability to effectively signal on it. The motion to recommit can only be offered by an opponent of a bill at the conclusion of debate. A motion to recommit with instructions that the committee report forthwith ensures the bill does not leave the floor and essentially provides the minority with an opportunity to offer an amendment of its choosing. A straight motion to recommit sends the bill back to the parent committee essentially killing the bill (Oleszek 2013). The motion is the prerogative of the minority party and is not provided with much notice to members, and the opposition does not have to give the proponents time to study any substantive changes that may result if the motion passes.

Republicans used the motion to recommit to frustrate majority party Democrats during the 110th Congress. As Oleszek $(2013,189)$ notes,

In the 2007-2008 period, Republicans artfully crafted recommit motions to attract support from Democrats elected from conservative districts. The result: they won adoption of the recommit motion twenty-five times compared to only fourteen agreed to when Democrats for a dozen years were the minority.

This led Democrats to alter rules governing the motion during the 111th Congress. ${ }^{6}$ Because the motion is not 
provided in advance, the majority party has limited opportunities to signal its opposition or support of it. Even if they had time to study the motion, they may not want to signal because a vote on the motion to recommit can be interpreted as voting on substance rather than procedure. While the motion often includes an amendment that may be difficult for majority party members to oppose, occasionally motions to recommit include substantive or technical amendments majority party leaders may support. ${ }^{7}$ For other procedural motions-like the motion to table - the timing and importance of the motion will vary on a case-by-case basis. As such, signaling should be observed, though less regularly then we would anticipate on special rules votes.

\section{Who Will Respond?}

In the event the majority party does issue a signal, which members are most likely to respond favorably? While the majority party wants to win, it frequently does not need its entire membership to fall in line to do so. Moreover, the party leadership is preoccupied with maintaining its majority status, and doing so occasionally requires placating representatives who represent cross-pressured districts (Arnold 1990). ${ }^{8}$ To maximize the likelihood the party will win while minimizing its loss of seats, the party leadership must be strategic in choosing when to pressure members on controversial legislation or key votes. Thus, when the party leadership finds it has more votes than necessary to pass a measure (or realizes that it does not have enough votes to be successful), it will release extraneous, cross-pressured members to vote with their constituencies. Otherwise, these legislators might find it difficult to support the party position on controversial legislation (King and Zeckhauser 2003).

Thus, we anticipate that while party leaders will talk tough on procedural votes, they will be most tolerant of defections from cross-pressured members-those who are generally positioned closer to the floor median. For example, in 2008, House Appropriations Chairman David Obey (D-WI) canceled a meeting with constituents from the office of Rep. Charlie Melancon (D-LA). Melancon defected on a vote to order the previous question on a special rule the day before, leading Obey to tell the party caucus that "anybody who wants to routinely vote against the leadership on procedural grounds, don't ask me to see their visiting firemen when they're in town" (Soraghan 2008). While the implication was that Melancon's constituents were not going to be able to meet with Obey (and thus be denied an opportunity to request a favorable earmark), Obey eventually relented and held the meeting the next day.

The expectation that more extreme majority party members are most likely to be influenced by partisan signaling from the leadership is consistent with recent work by Minozzi and Volden (2013), who examine rollcall votes with highly partisan elements. They report that members most likely to heed the call of the party are those "whose preferences most align with the party and who benefit the most from a strong, unified voice for their party" (Minozzi and Volden 2013, 799). Extremists benefit more than moderates from a strong, unified party brand and from keeping majority control of the chamber. They are also more likely to be in a safe electoral position and could absorb the costs of casting a party-line vote compared with more moderate members of the caucus.

Given what we know from the literature and our own observations of the House, we offer several hypotheses regarding the effect of party signals. First, if these signals carry any weight, we expect to find members supporting the leaderships' position more on signaled votes compared with non-signaled votes. This will provide some evidence that the signals are working. Second, as discussed above, we can also determine whether all members of the party vote in lock step with the leadership on agenda-setting votes when asked or if there is variation across different types of members based on their degree of liberalness. We expect to find the most liberal representatives rarely face this dilemma because the positions of their constituents and party are most likely similar. For more moderate representatives, they may feel cross-pressured from time to time and occasionally not support the signaled party position. The most conservative members of the Democratic Party are frequently put in a position where the views of their constituents are not the same as the leadership. In addition, conservative Democrats might actually pursue a deliberative strategy of voting against the leadership when they can to lower party support scores. This will help them avoid situations where opponents can run ads against them playing up how often they voted with Nancy Pelosi. Taken together, we expect liberals to respond to signals at high rates, moderates at lower rates, and conservatives not at all.

To summarize, we have expectations that the Leader's office will be more likely to signal on procedural, as opposed to substantive votes, because they are largely concerned with scheduling. In addition, they should signal on important procedural votes where they have enough time to formulate a party position (i.e., votes on special rules and previous question motions on special rules). We have argued that signaled votes should be more likely to attract party support than non-signaled votes and that extremists should be most responsive. In the next section, we show how the majority leadership uses emails to deliver floor updates on upcoming procedural votes in Congress. 


\section{Leader's Floor Updates}

To examine how the majority party instructs members on procedural votes, we use a new dataset that consists of the Democratic Leader's floor update emails for the second session of the 110th Congress and the entire 111th Congress. ${ }^{9}$ The majority leader's office sends these updates to Democratic members and their staff while Congress is in session multiple times throughout the day. ${ }^{10}$ Generally, there is a morning email (separate from the Daily Leader) that describes the legislative agenda for the day. Then, as votes approach, the office sends out additional emails, sometimes only minutes before the votes take place. On some votes, the emails provide simple instructions, or "signals," such as vote yes or no. For amendments, the emails frequently give a one or two sentence description of the substance of the amendment. The emails will often give warnings that the Republicans might offer dilatory motions such as the motion to adjourn or force a vote on approval of the House journal.

Figure 1 provides an example of one email with signals. For two votes, the motion to adjourn and the special rule, there are instructions to vote yes. For the two substantive votes, there are no instructions. In contrast to emails sent from the whip's office, the majority leader only sends signals on select votes. This suggests the leaders' emails are likely serving as a proxy for how salient the vote is to the majority, and as such, highlighting votes that are likely accompanied by positive agenda control techniques.

Table 1 provides a breakdown of the different types of votes taken by the House and the proportion of the time the party offered instructions. ${ }^{11}$ It is clear from the table that the party gives the majority of instructions on procedural votes while only offering a few instructions on substantive votes. In fact, the Majority Leader rarely provided instructions on the final passage of a bill or conference report.

Within the procedure category, as expected, the leadership frequently gives instructions on two types of important positive agenda-setting votes-moving the question on a special rule and then the vote on the rule. As noted above, it is essential that the party win on these votes, especially moving the previous question, because a loss can concede agenda-setting powers to the minority party. Instructions were commonly provided on motions to adjourn because losing this vote could shut down the session prematurely if offered by the minority Republicans, or cause the House to stay in session beyond a desired date when the motion is put forward by the majority party. In addition, the leadership frequently, but not always, supplied instructions on motions to table. Generally, a motion to table is used to dispense with other motions that might force the majority to take an uncomfortable vote. Finally, despite their importance, leaders rarely signaled the parties' position on the motion to recommit. Again, we feel this is largely due to the timing behind the motion to recommit.

\section{Preliminary Findings}

The next question we consider is the extent to which signals, such as an email from the majority leader, can matter. If they are at all effective, we should find a greater proportion of Democrats support the party on votes with instructions compared with votes without instructions. To test this hypothesis, we created two measures. The first is the proportion of time a member followed the signals, and the second is how often they voted with the party on non-signaled votes. In both categories, we only include procedural votes to increase comparability across the two measures. If we were to include final passage votes, they would almost all fall into the non-signaled category and certainly bias results toward lower levels of party support on non-signaled votes. ${ }^{12}$

To measure the party position on votes without signals, we initially compared how the majority leader, Steny Hoyer, and the majority whip, James Clyburn, voted. If they both voted the same way, we used that position as the party position. If they differed, or one of them did not vote, we coded the way the majority of the party voted as the party position. ${ }^{13}$ While the measures had a high of 1 for both Congresses, the minimum signaled vote proportion was .61 in the 110th Congress (Nick Lampson-Texas) and .29 in the 111th (Walt MinnickIdaho). Lampson also had the low score for non-signaled votes in the 110th Congress (.58) while Bobby Bright (AL-2) supported the party 44 percent of the time in the 111 th Congress.

We created Figures 2 and 3 to compare how members vote with different measures of preferences. They present four scatterplots of our party support measures plotted against two variables, a member's W-NOMINATE score (Poole and Rosenthal 2007) and the Democratic share of the presidential vote in their congressional district. In both figures, the closed circles are the scores for signaled votes while the open circles are for non-signaled votes. We also plotted simple Lowess curves to indicate the general trends in the data and put in vertical lines to denote the party and chamber median. It is clear from all the figures that the overall levels of party support are generally high across both types of votes. Party support for signaled votes (dashed lines) tends to be slightly higher across most of the variation in the $x$ axes, but not all of it, with support dropping off as members move from the party median toward the chamber median and beyond. Because W-NOMINATE and presidential vote run in opposing directions, we call all members to the liberal side of the party 


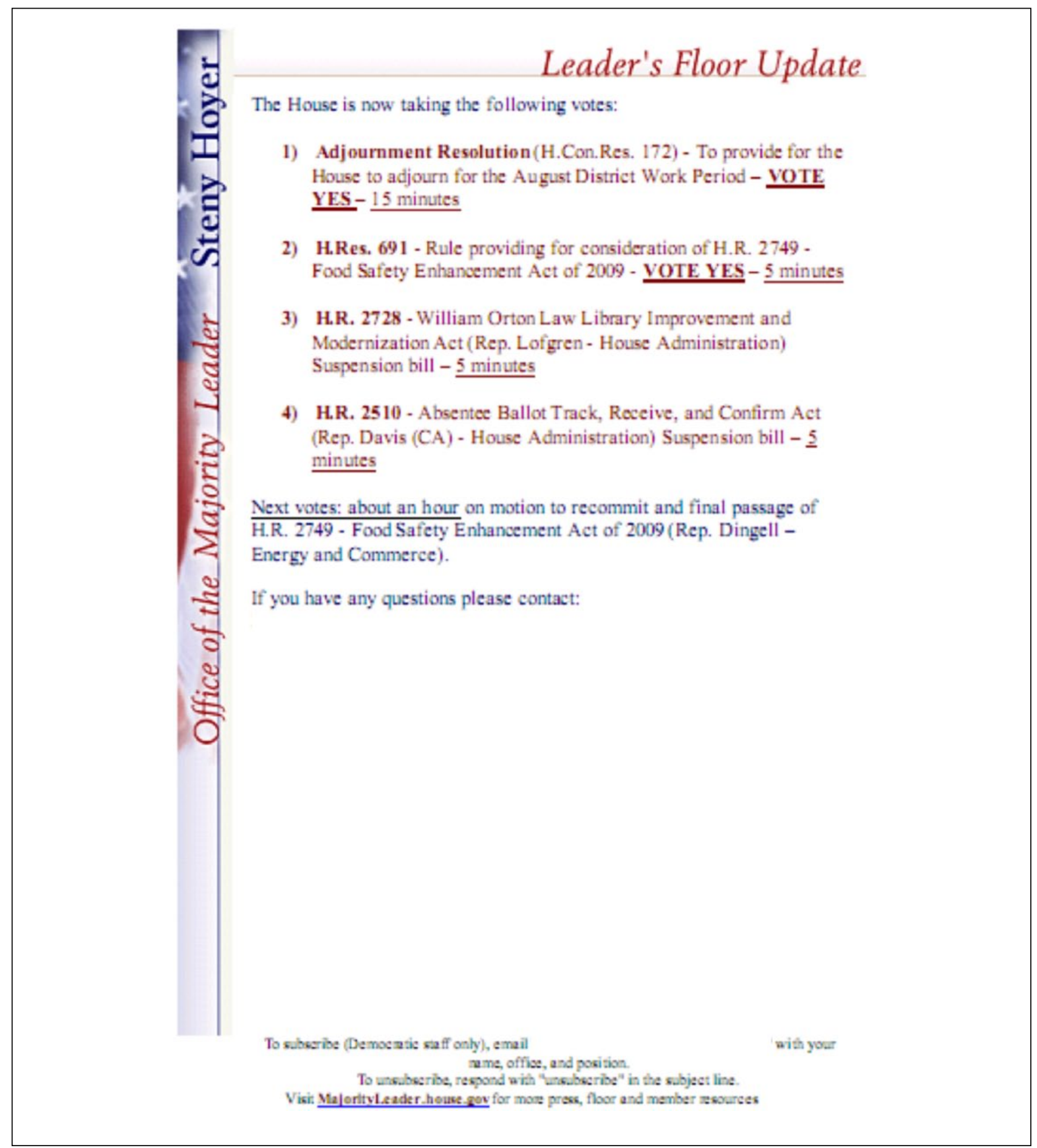

Figure I. Example of floor update.

median "liberals," between the party median and the chamber median "moderates," and on the opposite of the chamber median "conservatives." We picked these positions to test our hypotheses about who responds to signals because they are frequently important in relevant theories of legislative organization.
In Figure 2, we see that party support on signaled votes is nearly perfect for liberals for the 110th and the 111th Congresses. The pattern is similar, although at slightly lower rates for non-signaled votes. For moderate members, support is still high on both sets of votes, but the general trend is downward with a greater drop-off in 
Table I. Vote Types by Congress.

\begin{tabular}{|c|c|c|c|c|}
\hline \multirow[b]{2}{*}{ Vote type } & \multicolumn{2}{|c|}{ I IOth Congress } & \multicolumn{2}{|c|}{ II Ith Congress } \\
\hline & Total votes & $\%$ instructions & Total votes & $\%$ instructions \\
\hline \multicolumn{5}{|l|}{ Substantive and suspensions } \\
\hline Final passage of a bill & 45 & & 101 & 3.0 \\
\hline Final passage of conference report & 4 & & 12 & 8.3 \\
\hline Final passage of resolution & 2 & & 5 & 60.0 \\
\hline Final passage of joint resolution & & & 3 & \\
\hline Passage of a bill under suspension of the rules & 133 & & 304 & 0.3 \\
\hline $\begin{array}{l}\text { Passage of a joint resolution under suspension of } \\
\text { the rules }\end{array}$ & 2 & & 3 & \\
\hline Final passage of concurrent resolution & 7 & 14.3 & 18 & 72.2 \\
\hline $\begin{array}{l}\text { Passage of a concurrent resolution under } \\
\text { suspension of the rules }\end{array}$ & 18 & & 39 & \\
\hline $\begin{array}{l}\text { Passage of a resolution under suspension of the } \\
\text { rules }\end{array}$ & 86 & & 347 & \\
\hline Straight amendments & 82 & & 359 & 6.1 \\
\hline Passage over presidential veto & 5 & 20.0 & & \\
\hline Motion to suspend the rules and concur & 6 & & 14 & \\
\hline \multicolumn{5}{|l|}{ Procedural } \\
\hline Motion to reconsider & & & 16 & \\
\hline Appeal of the Chair's ruling & 2 & 50.0 & & \\
\hline Motion to recommit to conference & 1 & & 2 & 100 \\
\hline Motion to rise from the committee of the whole & 3 & 100.0 & 1 & \\
\hline Passage of special rule & 65 & 80.0 & 132 & 92.4 \\
\hline Motion to commit & & & 3 & 33.3 \\
\hline Motion to consider & 5 & 100.0 & 7 & 85.7 \\
\hline Motion to refer & 2 & & 8 & 87.5 \\
\hline Motion to order previous question & 1 & & 4 & 75.0 \\
\hline Election of speaker & & & I & \\
\hline Motion to recommit & 35 & & 65 & 12.3 \\
\hline Motion to instruct conferees & 10 & & II & \\
\hline Motion to table & 38 & 65.8 & 35 & 80.0 \\
\hline Motion to recede and concur & 16 & & 40 & 32.5 \\
\hline Previous question on special rules & 68 & 82.4 & 69 & 92.8 \\
\hline \multicolumn{5}{|l|}{ Dilatory } \\
\hline Motion to approve house journal & 13 & 92.3 & 13 & 100.0 \\
\hline Motion to adjourn & 39 & 79.5 & 19 & 63.2 \\
\hline Miscellaneous (non-dilatory) & & & 14 & 14.3 \\
\hline
\end{tabular}

the 111th Congress. For conservatives on the far side of the chamber median, the support is lower still. We also see the difference between the two categories declines and even crosses for a few members. We should be cautious, though, in drawing inferences about differences between groups in this last category due to the nature of Lowess curves and lack of statistical hypotheses tests. In Figure 3, the patterns appear to be generally similar with members from districts with a large Democratic base supporting the party at extremely high rates, a small drop-off for representatives between the two medians, and then a larger decline on the other side of the chamber median.
These figures offer what we think are some interesting preliminary findings. First, they show that the signals from the Majority Leader's office are effective as members appear to support the party at higher levels when they receive a signal. Second, they demonstrate that not all members support the party on procedural votes. This is an especially interesting result as much of the Congress literature to date has generally assumed that members of the majority party will simply vote with the party on procedural votes to facilitate control of the agenda. Although "enough" members support the party, some do not, even when asked. 


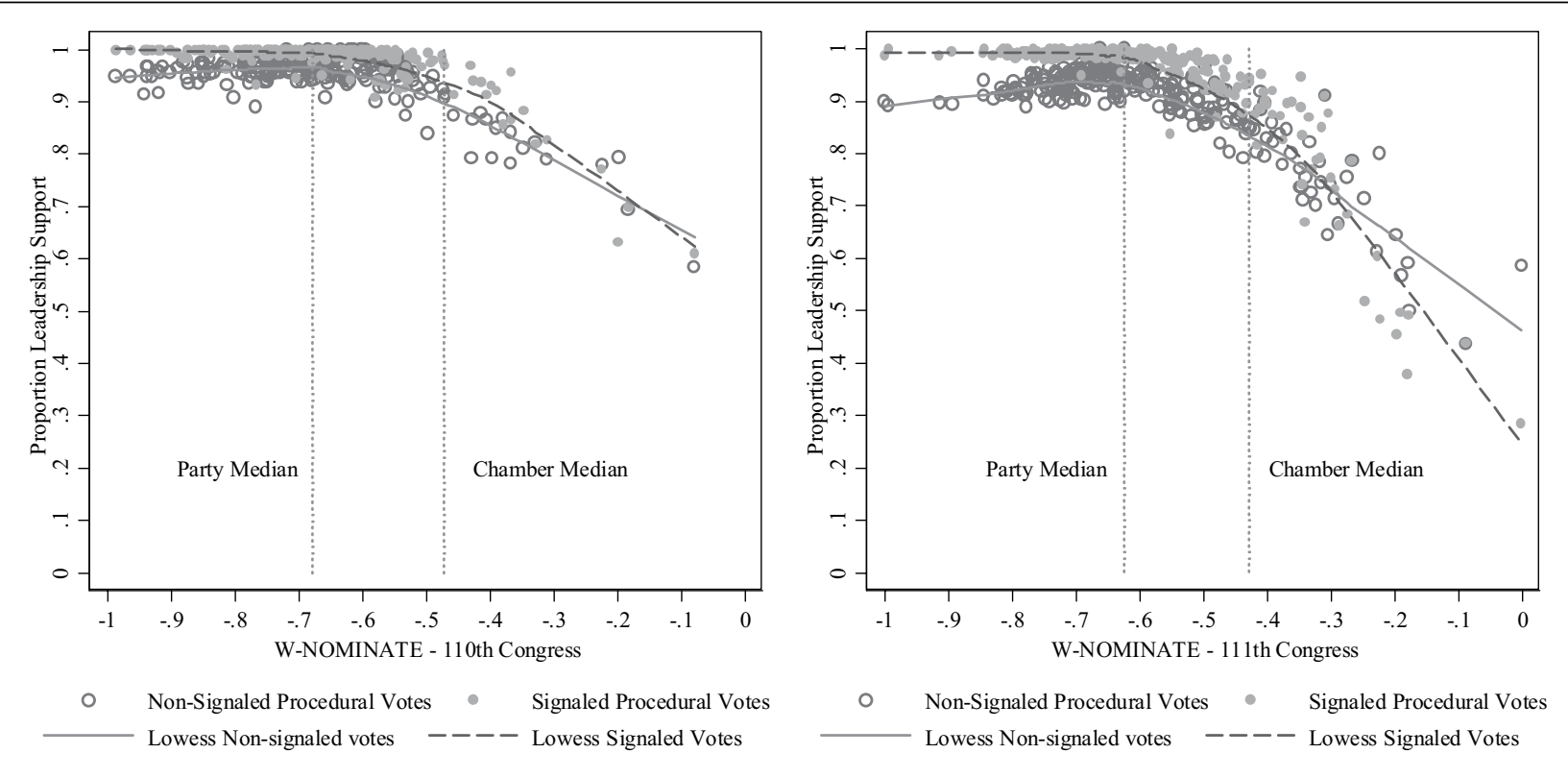

Figure 2. Proportion of leadership support by member ideology.

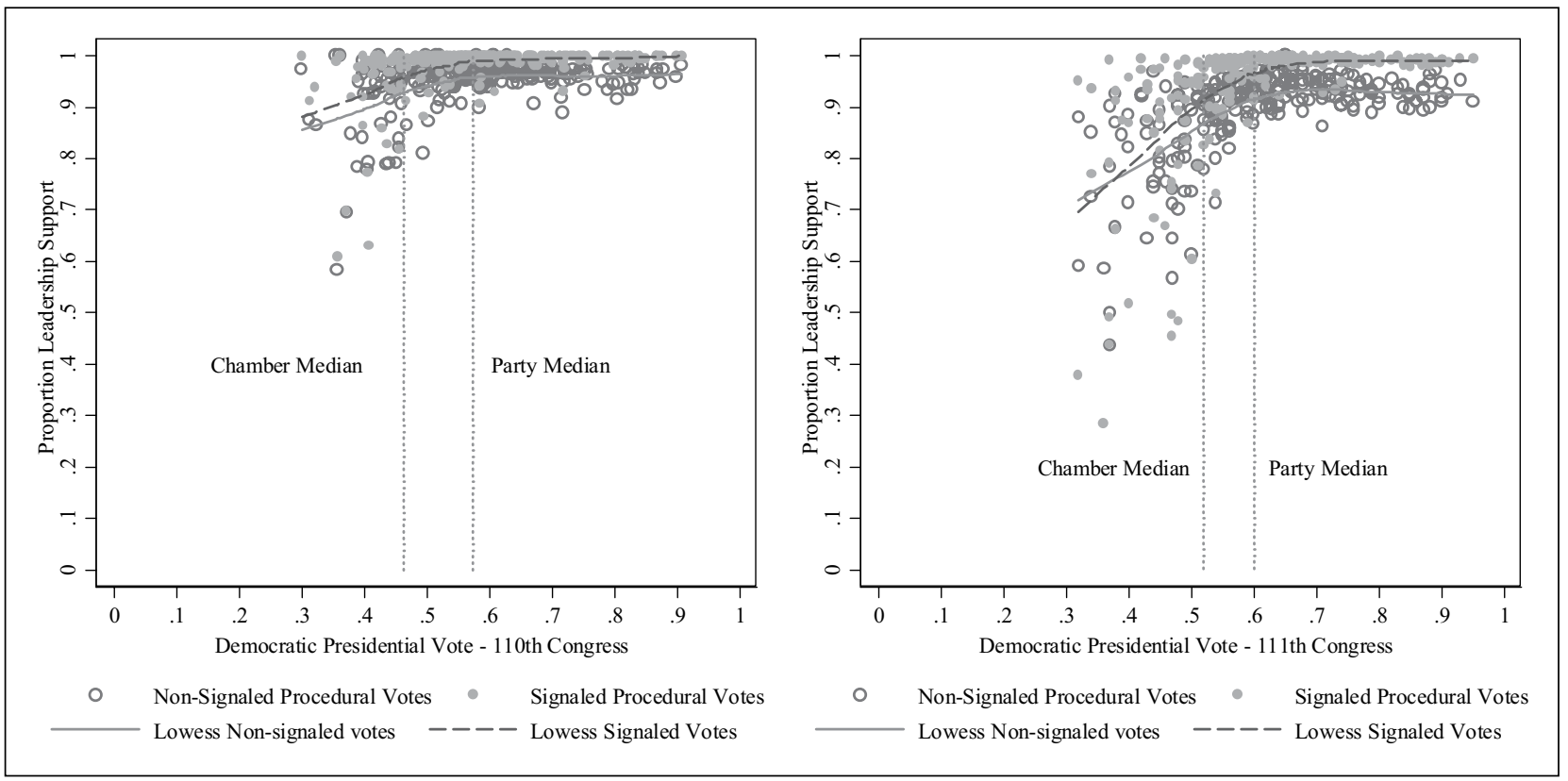

Figure 3. Proportion of leadership support by presidential vote.

In Table 2, we perform a series of difference of means tests to determine if members are more likely to vote with the party on procedural votes when they receive instructions. During the 110th Congress, Democrats voted with the party at a rate of .981 when there were instructions and .949 otherwise. For the 111th Congress, the difference was even larger, 4.8 (.946 vs. 898). These differences, along with a $t$ test when we pool the observations, are significant at the .05 level. Although the differences appear small, a difference of one percent of the Democratic majority corresponds to roughly 2.3 votes in the 110th Congress and 2.5 in the 111th Congress. Substantively, this means an average of 9.6 more Democrats voted with their party on procedural votes when the Leader's office gave instructions and indicates that instructions are effective 
Table 2. Proportion Voting with Leadership on Procedural Votes.

\begin{tabular}{lccc}
\hline & \multicolumn{3}{c}{ Vote type } \\
\cline { 2 - 4 } All groups & Signaled & Non-signaled & Difference \\
\hline I I Oth Congress & .981 & .949 & $0.032^{*}$ \\
III th Congress & .946 & .898 & $0.048^{*}$ \\
Pooled & .963 & .922 & $0.040^{*}$ \\
By group & & & \\
$\quad$ Liberal & .994 & .949 & $0.045^{*}$ \\
Moderate & .976 & .936 & $0.040^{*}$ \\
$\quad$ Conservative & .789 & .770 & 0.019 \\
\hline
\end{tabular}

*Difference significance at $p<.05$.

and may mean the difference between winning or losing on an extremely close vote.

We also examine differences across three groups-liberals, moderates, and conservatives based of off W-NOMINATE scores. Liberal Democrats appear to vote with the party on signaled votes nearly unconditionally, at a rate of .994 compared with .949 on non-signaled votes. For moderates between the medians, the difference is similar (.04), but the overall rates are a few points lower. These two differences are also statistically significant. Finally, when we examine the most moderate members, their support plummets below .80, although the difference between signaled and non-signaled votes is not significant. This finding helps to confirm the theoretical argument that moderates may be less responsive to the needs of the party when they come at the expense of their constituency (Mayhew 1974) and may not "heed the call of party" when called (Minozzi and Volden 2013). Taken together, these results are consistent with Finocchiaro and Rohde (2008) who find that member support of the party on procedural votes is clearly conditional. The difference here is we examine individual members rather than particular votes.

\section{Results}

To determine whether our results hold up to systematic scrutiny, we estimate several models where the dependent variable is measured the same as above - the proportion of the time a member votes with the party on signaled and also non-signaled roll calls. Because our dependent variable is a proportion, we estimate a generalized linear model (GLM) with a logit link and the binomial family. ${ }^{14}$ To test whether there is a difference between the two, we include a dichotomous variable, signaled, that is coded one for each members' signaled vote score and zero for non-signaled votes. ${ }^{15}$ In additional estimations, we test several hypotheses about where support is high and where it drops off.
In addition to the signaled variable, we include a few control variables in our model. We expect members from districts with a strong Democratic base should vote with the party more often, all else equal. This conjecture holds for two reasons. First, a Democrat with a strong base does not always have to decide between voting with her district and voting with the party. On most votes, the two positions are similar enough that when a member votes with the party, she is also voting with her constituents. However, members who represent districts with a smaller Democratic base are often forced to cast votes that either support the party or the voters back home (but not both). Second, we also expect that the amount of Democratic support in the district and a member's electoral safety should be highly correlated. As such, members from strong Democratic districts can support the party more often, even if it means occasionally voting against the district, and still feel secure about returning to Congress year after year (on this point, see Carson et al. 2010). We measure Democratic base as the Democratic presidential candidate's share of the two-party vote in the election prior to the respective Congress.

We also expect that candidates who faced a primary challenge could support the party differently compared with legislators who did not have to contend for their party's nomination. Depending on if the challenge is from the left or the right, the representative may support the party at higher or lower rates. If a member has to worry about a challenge from within her own party, she needs to be particularly careful not to stray from the district's views on the issues. While most constituents do not routinely pay attention to procedural votes, a primary challenger will likely use a high (or low) party support score as a way to show the member is out of touch with the district. To measure this concept, we include a dichotomous variable, Primary Challenge, coded one for members who faced a primary challenger and zero otherwise. $^{16}$

In addition, we include a dichotomous variable, Freshman, to determine whether freshman members are more or less likely to support the party leadership. From one perspective, it would make sense for freshmen to be more deferential to the party given that they are new to the job and often must seek guidance elsewhere in terms of how to vote (Kingdon 1989). Members in the party leadership provide a good source for cues in this sense and can often reward loyal freshmen with campaign money for their next election (Cann 2008). An alternative perspective emphasizes the individual ideological qualities of those legislators. In the 110th and 111 th Congresses, the Democratic Party saw an influx of members from more conservative House districts, which could result in an increased propensity for member defections among these freshmen legislators. Finally, we also include a 
Table 3. GLM Estimation of Party Support.

\begin{tabular}{|c|c|c|c|c|c|c|c|c|c|c|}
\hline \multirow[b]{2}{*}{ Variables } & \multicolumn{2}{|c|}{ Base model } & \multicolumn{2}{|c|}{ Groups (signaled only) } & \multicolumn{2}{|c|}{ Liberal } & \multicolumn{2}{|c|}{ Moderate } & \multicolumn{2}{|c|}{ Conservative } \\
\hline & $\begin{array}{c}\text { Coefficient } \\
\text { (SE) }\end{array}$ & $\begin{array}{c}\text { Marginal } \\
\text { effect }\end{array}$ & $\begin{array}{c}\text { Cooefficient } \\
\text { (SE) }\end{array}$ & $\begin{array}{c}\text { Marginal } \\
\text { effect }\end{array}$ & $\begin{array}{c}\text { Coefficient } \\
\text { (SE) }\end{array}$ & $\begin{array}{c}\text { Marginal } \\
\text { effect }\end{array}$ & $\begin{array}{c}\text { Coefficient } \\
\text { (SE) }\end{array}$ & $\begin{array}{c}\text { Marginal } \\
\text { effect }\end{array}$ & $\begin{array}{l}\text { Coefficient } \\
\text { (SE) }\end{array}$ & $\begin{array}{c}\text { Marginal } \\
\text { effect }\end{array}$ \\
\hline $\begin{array}{l}\text { Signaled } \\
\text { vote }\end{array}$ & $0.80 *(0.083)$ & $0.031[0.045]^{\mathrm{a}}$ & & & $2.19 *(0.10)$ & $0.044[0.050]^{\mathrm{a}}$ & $1.03^{*}(0.075)$ & $0.037[0.050]^{\mathrm{a}}$ & $0.12(0.10)$ & $0.019[0.011]^{\mathrm{a}}$ \\
\hline $\begin{array}{l}\text { Democratic } \\
\text { base }\end{array}$ & $5.06 *(0.58)$ & 0.19 & $4.12 *(0.94)$ & 0.056 & $-0.80 *(0.31)$ & -0.014 & $1.84 *(0.46)$ & 0.063 & $6.22 *(1.21)$ & 1.03 \\
\hline $\begin{array}{l}\text { Primary } \\
\text { challenge }\end{array}$ & $-0.056(0.10)$ & -0.0022 & $0.18(0.19)$ & 0.0023 & $-0.10(0.11)$ & -0.0018 & $-0.13(0.16)$ & -0.0048 & $0.29 *(0.13)$ & 0.046 \\
\hline Freshman & $-0.59 *(0.11)$ & -0.027 & $-0.30 *(0.15)$ & -0.0045 & $-0.11(0.091)$ & -0.0020 & $-0.22^{*}(0.11)$ & -0.0083 & $-0.34 *(0.15)$ & -0.057 \\
\hline $\begin{array}{l}\text { I10th } \\
\text { Congress }\end{array}$ & $1.07 *(0.076)$ & 0.042 & $0.99 *(0.14)$ & 0.014 & $0.49 *(0.056)$ & 0.0082 & $1.00 *(0.079)$ & 0.036 & $0.94 *(0.16)$ & 0.14 \\
\hline Liberal & & & $2.65^{*}(0.26)$ & $0.046[0.130]^{\mathrm{a}}$ & & & & & & \\
\hline Moderate & & & $1.83 *(0.17)$ & $0.023[0.116]^{\mathrm{a}}$ & & & & & & \\
\hline Constant & $-0.66(0.35)$ & & $-0.67(0.46)$ & & $3.29 *(0.22)$ & & $1.34 *(0.25)$ & & $-1.70 *(0.55)$ & \\
\hline$N$ & 986 & & 493 & & 492 & & 376 & & 118 & \\
\hline $\mathrm{AIC}$ & 0.32 & & 0.21 & & 0.21 & & 0.29 & & 0.82 & \\
\hline
\end{tabular}

Standard errors clustered by member in parentheses; AIC = Akaike information criterion.

${ }^{\text {a }}$ First difference holding all other variables at means or modes.

$* p<.05$.

dichotomous variable coded one for the 110th Congress to account for differences between the two congresses.

We present the results from the initial estimation in the columns labeled "Base Model" in Table 3. To provide a substantive interpretation of our hypotheses, we calculate first differences in the change of the proportion of party support for key variables. These numbers appear in brackets in Table 3. In the base model, we continue to find that members vote with the party at greater proportions (.045) when the party sends a simple signal in an email. The control variables work as we expected as members with a larger Democratic base vote with the party at higher levels. Representatives who faced a primary challenge and freshman were also less likely to toe the party line. In addition, we created Figure 4, which provides a predicted measure of mean party support for both types of votes over the range of our Democratic Base variable. The dashed line is for signaled votes, while the solid line is for non-signaled votes. In both cases, the shaded areas represent 95 percent confidence intervals. In line with our theoretical expectations, we find the support for signaled votes to be higher with relatively low levels from the most conservative districts and much higher support as districts become more liberal. The difference is not significant at the highest levels, but this is because both predicted proportions are near the maximum of one. While the difference is significant for relatively conservative members, this figure represents average effects and is not a direct test of our group hypotheses. We will turn to that next.

In the following estimation, which only includes signaled votes in the dependent variable, we include dichotomous variables for two of the three groups-liberal and moderate - and leave the conservative group as the

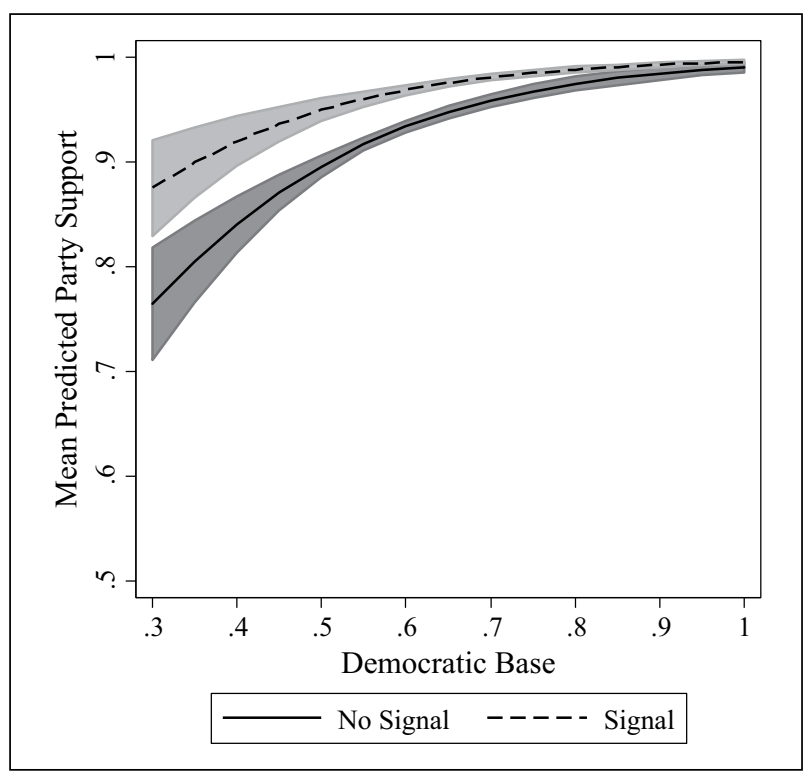

Figure 4. Predicted support on signaled and non-signaled votes: base model.

reference category. This allows us to test for differences between the different types of members when the leadership sends a signal. The coefficients on the Liberal and Moderate variables are positive and significant indicating the level of support for these groups is statistically greater compared with the reference category. Similar to the results in Table 2, the proportion of support for the party is greatest for the most liberal grouping of members. A Wald test indicates that the difference between the liberal and moderate groups is also statistically significant at the .01 level. When we only examine signaled votes, liberal 


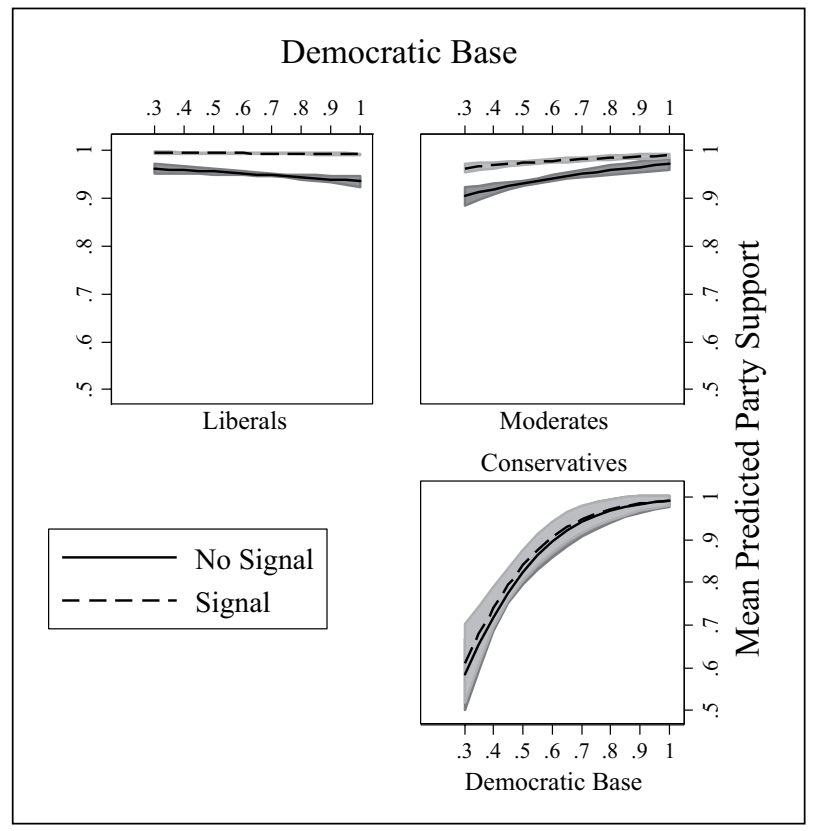

Figure 5. Predicted support on signaled and non-signaled votes: liberals, moderates, and conservatives.

members show a first difference increase of support of .130 compared with .116 for the moderate category.

Finally, we estimate three additional models using just the members in each of the groups. ${ }^{17}$ Now, the signal variable tells us if representatives in each of the groups are supporting the party at higher levels when a signal is sent by the Leader. Members in the liberal and middle groups appear to be responsive to signals on procedural votes, increasing their support at similar levels. Although the first differences are nearly identical, there is not much room for improvement for the most liberal group as they are starting from a much higher baseline. For the members on the other side of the floor median, they show no difference when a signal is sent. Figure 5 plots the mean predicted party support score over the range of the Democratic Base variable with 95 percent confidence intervals in the shaded region. It shows us that the support on signaled votes is near 1 for liberals and significantly lower (although still high) for non-signaled votes. The results are similar for moderates with increasing support across the range. Finally, there is no difference between the two types of votes for members in the conservative category.

The controls also vary across the three groups in substantively interesting ways. The Democratic Base coefficient is now negative and small for the liberal group, positive and slightly larger for the middle group, and even larger for the right group. This large coefficient for the conservative group means that moderate members are very responsive to changes in their base, while the influence is quite small for the other groups. Once we separate out the three categories, it appears that the moderate and conservative groups of freshmen are less likely to vote with the party on procedure, while there is no difference for the liberal grouping. The effect appears to be largest for the conservative group suggesting this crop of freshman may be deliberately voting against the rest of their party. To summarize, we find that, in general, rankand-file members vote with the leadership on procedural votes and at even higher rates when the Leader's office sends a signal. However, members who face cross-pressure from their districts are the least responsive to signals in what we think is an attempt to keep party support scores low and to distance themselves from the Democratic Leadership in both style and substance.

\section{Conclusion}

In this article, we set out to accomplish three things. First, we wanted to document the micro-level role that the majority party plays in signaling legislators on how to vote on important agenda-setting motions and resolutions. In essence, we are able to verify how the Democratic Leadership solves the coordination problem to maintain control of the agenda. Although we are continuing to learn much about the whip system and its role in positive agenda control in Congress (see Evans and Grandy 2009), we know significantly less about the influence of party leadership prior to substantive votes occurring on the floor. In particular, this article has shown that the majority party is cognizant of the balance legislators must maintain to get reelected and support the party platform. As such, the leadership is more likely to signal positions on procedural matters where traceability is much lower and the risks to legislators are reduced (Arnold 1990). We show here that party leaders are much more likely to signal their position on certain types of procedural voteswhen winning is essential and when they have the time to study the possible substantive changes. If substantive outcomes are unclear or if the vote is viewed as less essential, the leadership sends signals at much lower rates. We think this finding is telling given the emphasis prior research has placed on the motion to recommit, although our result may be specific to the short time where we have data. On other votes such as final passage and amendments where traceability is high, the Majority Leader offers little guidance to members, and we believe this task is left to the formal and informal whip system.

The second goal for this article was to begin to document an as yet understudied aspect of the legislative process. Prior research has often tried to measure the leadership's position on key votes taken in Congress by using various statistical techniques to estimate "ideal points" or other positions. We introduce a new dataset 
that provides a direct measure of the party leadership's position on an important set of votes. The data that we use in this article offer a viable, alternative specification that is known rather than estimated, and future work can use these to tap into the majority's position on some votes taking place in the House. Use of this measure could be important to students of congressional politics seeking to determine the role party plays in influencing rank-and-file member behavior on salient votes.

Our third and final goal in this article was to apply the measure of partisan signaling to the individual decision-making processes used by rank-and-file legislators. Specifically, we wanted to determine what factors led to members adopting the majority party's position. We show that while procedural votes may lack traceability, party support among the rank-and-file membership is by no means assured. Our results echo recent work by Minozzi and Volden (2013) suggesting that responsiveness to party signals is not simply concentrated among majority party moderates; rather, it varies significantly across the ideological spectrum of majority party members.

In particular, we found that legislator ideology and constituency influence were important predictors in this decision calculus for some, but not all, members. Liberal members supported the leadership at extremely high rates across all types of procedural votes and did so nearly perfectly when signaled. In contrast, more conservative members on the opposite side of the floor median, who were generally not needed to obtain a majority on any particular vote, supported the party at much lower rates on agenda-setting votes and were not responsive to the signals. We think these results are important because they reinforce the idea that while support for the leadership is high, and the majority party is rarely rolled, it does not imply that all members toe the party line, even when the votes are harder to trace back to substantive changes in policy outcomes.

In future research, we think it would be worthwhile to examine the effects of defection on procedural votes. A cursory examination of the data show some conservative Democrats appear to "run away" when the leadership sends signals while others toe the line. Through a mix of interviews and other methods, we hope to learn if this technique is deliberate and if there are any electoral benefits to the strategy. While we only have data for one party and for a limited time frame, we could make some assumptions and run simulations to estimate results for different time periods or for the Republican Party. Carrying out these lines of research would allow us to learn more about the day-to-day operation of the Congress and perhaps how the parties are able to overcome collective action problems to pass legislation.

\section{Declaration of Conflicting Interests}

The author(s) declared no potential conflicts of interest with respect to the research, authorship, and/or publication of this article.

\section{Funding}

The author(s) received no financial support for the research, authorship, and/or publication of this article.

\section{Notes}

1. Platform-type votes include most economic issues-such as budgets, social security, and the debt ceiling.

2. Typically, this will entail arm-twisting, promising favors, engaging in vote buying, and whipping recalcitrant members on crucial or important votes (see Aldrich and Rohde 2000).

3. See, for example, this ad stating Martin Heinrich (D-NM) voted with Nancy Pelosi 97 percent of the time (https://www.youtube.com/watch?v=oLDzo_CvtG0 accessed 3/23/14) or this ad "Her Congressman" asserting Glenn Nye (D-VA) voted with Pelosi 83 percent of the time (https://www.youtube.com/watch? $\mathrm{v}=\mathrm{pVxOt} 0 \mathrm{NzfG}$ accessed 3/23/14). Jim Marshall (D-GA) went the opposite direction, stating he voted with Republican leaders 65 percent of the time (https://www.youtube.com/watch? $\mathrm{v}=003$ dcjNYZA accessed 3/23/14).

4. H.R. 4853 was originally a short-term extension of the Federal Aviation Administration Act. H. Res. 1745 made it to agree to a Senate amendment to H.R. 4853 with a substitute amendment that inserted the text of H.R. 6467, the Middle Class Tax Relief Act of 2010. By using H.R. 4853 as a vehicle, Democrats allowed majority leader Reid to avoid a filibuster on the motion to proceed and allowed them to block minority party Republicans from offering a motion to recommit (Sloan 2010). An amended version of the bill was passed by the Senate, concurred by the House and signed into law by the President on December 16, 2010 (P.L. 111-312).

5. The majority party likely knows it will be unable to count on any minority party support. Even when a special rule is comparatively open, the minority is likely to have an additional amendment it wants considered. For example, on March 17, 2009, the House considered H. Res. 250, which provided for consideration of the Serve America Act under a structured rule. The rule made in order all proposed amendments by minority party Republicans. Rep. Lincoln Diaz-Balert (R-FL) conceded this point, noting that "I know the majority is trumpeting this rule with which we bring this underlying legislation to the floor because it will allow Members to debate all of the amendments that were submitted to the Rules Committee by Republicans. And that's appropriate. Nevertheless, I remind my colleagues the majority does this when the underlying legislation is uncontroversial" (Congressional Record, 111th Congress, March 17, 2009, H3537). Despite this fairly open process, Republicans opposed ordering the previous question Rep. Steven LaTourette (R-OH) explained his position: "I 
intend to vote 'no' on the previous question on this particular rule. I don't have any big problem with the rule, but it is my understanding that Mr. Diaz-Balart will, if it is defeated, offer an amendment to the rule that will address a topic that isn't the subject of the GIVE Act, but the AIG bonuses" (Congressional Record, 111th Congress, March 18, 2009, H3540).

6. Republicans aggressively opposed these rule changes. Rules Committee ranking member David Drier (R-CA) argued that "process is substance" and noted that the Democrats were restricting the one motion that "ensures that the minority gets at least one opportunity to offer an amendment or an alternative" (Congressional Record, 111th Congress, January 6, 2009, H6-H20).

7. In other cases, the motion may not alter the bill in any substantial way. For example, in 2009, minority party Republicans offered a motion to recommit with instructions to H.R. 2847, the Commerce-Justice-Science Appropriations Act. The bill manager, Rep. David Obey (D-WI), responded to the motion by stating, "Do you know what [this motion] does? It don't do nothing. All it does is give one of our friends on that side of the aisle a chance to talk about an issue. I want to congratulate him. That's the least destructive thing they've done today. I simply want to say that, if this amendment passes, there is no way it can be interpreted by the implementing agency to have anything whatsoever to do with the issue that the gentleman just talked about, because the amendment has no effect on it" (Congressional Record, 111th Congress, June 18, 2009, $\mathrm{H7015).}$

8. As Mayhew $(1974,99)$ argues, "There is no member of either house who would not be politically injured-by being made to toe a party line on all policies (unless of course he could determine the line)."

9. The emails were forwarded to one of the authors on a realtime basis from a Democratic staff member.

10. We should point out that we cannot provide direct evidence that members are reading these emails and using the information to decide how to vote. However, the emails are just one of many ways the Majority Leader's office can provide this information and because several go out per day, it appears that the office thinks they carry some value. In addition to the emails we describe here, the Majority Leader also sends out the Weekly and Daily Leader that lay out the expected votes for the day or week. These emails do not include any instructions. We should also note that these emails are both different and separate from the Daily and Weekly Whip reports.

11. The PIPC program at Duke University coded the vote types for the 110th Congress while the authors coded the votes for the 111 th Congress.

12. Crespin (2010) finds that representatives are responsive to constituents on substantive votes and the party on procedure.

13. This happened quite rarely. Either one or both of them was absent in just over 4 percent of the observations in our dataset. In addition, Hoyer and Clyburn cast opposing votes in just over 1 percent of the votes in our dataset. The roughly 95 percent of remaining instances saw them present and voting in the same direction. In both congresses, the leadership's position matched the signaled position in all but one instance (or well over $99 \%$ of cases).

14. The generalized linear model (GLM) is more appropriate given the distribution of our dependent variable with many cases near 1 . Results are similar using ordinary least squares (OLS).

15. This means each member is included in the estimate twice for each congress. For this reason, we cluster the standard errors on each representative, using STATA's cluster command. See Froot (1989) and Williams (2000) for more details on clustering.

16. Because some members face only token competition in a primary, we coded members who received 90 percent or more of the primary vote as a zero. Freshmen legislators were omitted from this coding.

17. An alternative approach is to interact the group variables with the signal variable. In the end, we decided the ease of interpretation was worth the decrease in efficiency.

\section{References}

Aldrich, John H., and David W. Rohde. 2000. "The Consequences of Party Organization in the House: The Role of Majority and Minority Parties in Conditional Party Government." In Polarized Politics: Congress and the President in a Partisan Era, edited by Jon Bond and Richard Fleisher, 31-72. Washington, DC: CQ Press.

Arnold, R. Douglas. 1990. The Logic of Congressional Action. New Haven: Yale University Press.

Binder, Sarah A., Eric D. Lawrence, and Forrest Maltzman. 1999. "Uncovering the Hidden Effect of Party." Journal of Politics 61:815-31.

Cann, Damon M. 2008. Sharing the Wealth: Member Contributions and the Exchange Theory of Party Influence in the U.S. House of Representatives. Albany: State University of New York Press.

Carson, Jamie L., Gregory Koger, Matthew J. Lebo, and Everett Young. 2010. "The Electoral Costs of Party Loyalty in Congress." American Journal of Political Science 54 (3): 598-616.

Carson, Jamie L., Nathan Monroe, and Greg Robinson. 2011. "Unpacking Agenda Control in Congress: Individual Roll Rates and the Republican Revolution." Political Research Quarterly 64:17-30.

Cox, Gary W. 2000. "On the Effects of Legislative Rules." Legislative Studies Quarterly 25:169-92.

Cox, Gary W., and Mathew D. McCubbins. 2005. Setting the Agenda: Responsible Party Government in the U.S. House of Representatives. New York: Cambridge University Press.

Cox, Gary W., and Mathew D. McCubbins. 2007. Legislative Leviathan: Party Government in the House. 2nd ed. New York: Cambridge University Press.

Cox, Gary W., and Keith T. Poole. 2002. "On Measuring Partisanship in Roll-Call Voting: The U.S. House of Representatives, 1977-1999." American Journal of Political Science 46:477-89. 
Crespin, Michael H. 2010. "Serving Two Masters: Redistricting and Voting in the U.S. House of Representatives." Political Research Quarterly 63 (4): 850-85.

Evans, C. Lawrence, and Claire E. Grandy. 2009. "The Whip System of Congress." In Congress Reconsidered, 9th ed., edited by Lawrence Dodd and Bruce Oppenheimer,pp. 189-215. Washington, DC: CQ Press.

Finocchiaro, Charles J., and David W. Rohde. 2008. "War for the Floor: Partisan Theory and Agenda Control in the U.S. House of Representatives." Legislative Studies Quarterly 33 (1): 35-61.

Froot, Kenneth A. 1989. "Consistent Covariance Matrix Estimation with Cross-Sectional Dependence and Heteroskedasticity in Financial Data." Journal of Financial and Quantitative Analysis 24:333-55.

Gailmard, Sean, and Jeffery Jenkins. 2007. "Negative Agenda Control in the Senate and House of Representatives: Fingerprints of Majority Party Power." Journal of Politics 69 (3): 689-700.

Jenkins, Jeffery, Michael H. Crespin, and Jamie L. Carson. 2005. "Parties as Procedural Coalitions in Congress: An Examination of Differing Career Tracks." Legislative Studies Quarterly 30 (3): 365-89.

Jenkins, Jeffery, and Nathan Monroe. 2012a. "Buying Negative Agenda Control in the U.S. House." American Journal of Political Science 56 (4): 897-912.

Jenkins, Jeffery, and Nathan Monroe. 2012b. "Partisan Agenda Control in the U.S. House: A Theoretical Exploration." Journal of Theoretical Politics 24:555-70.

King, David C., and Richard Zeckhauser. 2003. "Congressional Vote Options.” Legislative Studies Quarterly 28 (3): 387 411.

Kingdon, John W. 1989. Congressmen's Voting Decisions. 3rd ed. Ann Arbor: University of Michigan Press.

Krehbiel, Keith. 1993. "Where's the Party?" British Journal of Political Science 23:235-66.

Krehbiel, Keith, and Adam Meirowitz. 2002. "Minority Rights and Majority Power: Theoretical Consequences of the Motion to Recommit." Legislative Studies Quarterly 27:191-218.
Marshall, Bryan W. 2005. Rules for War: Procedural Choice in the U.S. House of Representatives. Vermont: Ashgate Publishing.

Mayhew, David R. 1974. Congress: The Electoral Connection. New Haven: Yale University Press.

Minozzi, William, and Craig Volden. 2013. "Who Heeds the Call of the Party in Congress?" Journal of Politics 73 (3): 787-802.

Monroe, Nathan W., and Gregory Robinson. 2008. "Do Restrictive Rules Produce Non-median Outcomes? A Theory with Evidence from the 101st-108th Congresses." Journal of Politics 70 (1): 217-31.

Oleszek, Walter. 2013. Congressional Procedures and the Policy Process. 9th ed. Washington, DC: CQ Press.

Poole, Keith T., and Howard Rosenthal. 2007. Ideology and Congress. New Jersey: Transaction Publishers.

Roberts, Jason M. 2005. "Minority Rights and Majority Power: Conditional Party Government and the Motion to Recommit in the House." Legislative Studies Quarterly 30 (2): 219-34.

Rohde, David. 1991. Parties and Leaders in the Postreform House. Chicago: University of Chicago Press.

Sloan, Steven. 2010. "Some House Moderates Unhappy with Tax Vote Procedure." CQ Today, December 2. http://www. cq.com/doc/news-3771922.

Smith, Steven S. 1989. Call to Order: Floor Politics in the House and Senate. Washington, DC: The Brookings Institution Press.

Smith, Steven S., Ian Ostrander, and Christopher M. Pope. 2013. "Majority Party Power and Procedural Motions in the U.S. Senate." Legislative Studies Quarterly 38 (2): 205-36.

Snyder, James M., Jr., and Tim Groseclose. 2000. "Estimating Party Influence in Congressional Roll-Call Voting." American Journal of Political Science 44 (2): 193-211.

Soraghan, Mike. 2008. "Obey Lays Down the Law on Procedural Votes." The Hill, March 14. http://thehill.com/ homenews/news/14564-obey-lays-down-the-law-on-procedural-votes\#ixzz2vgeWWahQ.

Williams, Rick L. 2000. “A Note on Robust Variance Estimation for Cluster-Correlated Data.” Biometrics 56:645-46. 